\title{
Overfeeding during early pregnancy reduces peripheral progesterone concentration and pregnancy rate in sheep
}

\author{
R. A. Parr, I. F. Davis, R. J. Fairclough and M. A. Miles \\ Animal Research Institute, Department of Agriculture and Rural Affairs, Werribee, Victoria 3030, \\ Australia
}

\begin{abstract}
Summary. The 330 Merino ewes used in the study were placed with rams at a synchronized oestrus and, on Days 2-14 after mating, the ewes were placed in a feed lot and fed daily a low, medium or high ration $(25 \%, 100 \%$ or $200 \%$ of maintenance respectively). Progesterone supplement was given to some ewes on Days 8-14 after mating by using a device containing $340 \mathrm{mg}$ progesterone. Blood samples were taken from all ewes on Day 12 for measurement of plasma progesterone concentrations. On Day 14 after mating all ewes were returned to pasture. Pregnancy rate was determined by returns to oestrus and was later confirmed using ultrasound.

There was a decline in the peripheral progesterone concentrations with increasing ration. The pregnancy rate in ewes fed a high ration was significantly reduced when compared with those of ewes fed a medium or low ration $(48 \%$ vs 68 and $67 \%$ respectively; $P<0.05)$. In ewes fed the high ration exogenous progesterone increased the pregnancy rate from 48 to $76 \%(P<0.01)$. Progesterone treatment did not influence pregnancy rates in ewes fed medium or low rations. The number of fetuses per ewe pregnant was not influenced by level of nutrition or progesterone treatment.
\end{abstract}

\section{Introduction}

It is now well established that between 20 and $30 \%$ of fertilized sheep ova die in the first weeks of pregnancy (Edey, 1969). However the factors responsible for these relatively high embryonic losses are still uncertain. Progesterone may play a role since it is essential for the maintenance of pregnancy in the ewe (Denamur \& Martinet, 1955). Exogenous progesterone has been used by some workers in an attempt to improve embryonic survival in sheep. In some studies (Pearce et al., 1984; Peterson et al., 1984; Davis et al., 1986) increases in pregnancy rates of 11-28\% have been achieved using progestagen supplements, although other reports have demonstrated no such benefit (Smith et al., 1985; Kerton et al., 1986). A possible explanation for these conflicting results may be differences in the nutritional status of the ewes during the treatment period. Since nutrition in early pregnancy and peripheral progesterone concentrations are inversely related (Parr et al., 1982; Williams \& Cumming, 1982), we investigated the relationship between nutrition, progesterone supplementation and the pregnancy rate of ewes.

\section{Materials and Methods}

Mature Merino ewes $(\mathrm{N}=330)$ were treated with intravaginal controlled internal drug-release devices (CIDR: Hoechst Australia Ltd, Melbourne, Victoria) to synchronize oestrus and then mated with entire rams ( 20 in total). On Day 2 after mating (Day $0=$ day of oestrus) the ewes were placed in a feed-lot and given low, medium or high rations $(25 \%, 100 \%$ or $200 \%$ maintenance respectively). Ewes were randomly distributed to provide 110 in each nutrition treatment group and were fed daily for 12 days. The rations consisted of a pelleted lucerne/barley mixture $(50 / 50$, $\mathrm{w} / \mathrm{w}$ ) and contained $11.2 \mathrm{MJ}$ metabolizable energy $/ \mathrm{kg}$ dry matter and $10 \cdot 5 \%$ crude protein. They were fed as a supple- 
ment to pasture for 3 weeks before the start of the experiment. A CIDR device containing $340 \mathrm{mg}$ progesterone was placed in the vagina of half the ewes in each nutritional treatment group on Day 8 and was removed on Day 14 after mating when all ewes were returned to pasture. Blood samples were taken 12 days after mating into a heparinized syringe, centrifuged and the plasma was stored at $-20^{\circ} \mathrm{C}$ for progesterone assay.

Plasma progesterone concentrations were analysed by a modification of the method of Fairclough et al. (1975). Briefly, plasma samples were extracted in duplicate with hexane and the dried extract was resuspended in phosphosaline buffer $\left(0.01 \mathrm{M}, \mathrm{pH} \mathrm{7.4)}\right.$; the assay mix contained progesterone antiserum diluted to $1: 2000$ and $6 \mathrm{nCi}\left[{ }^{3} \mathrm{H}\right]-$ progesterone. After incubating overnight at $4^{\circ} \mathrm{C}$ the free and bound progesterone were separated using dextrancoated charcoal $(0.8 \mathrm{mg}$ charcoal, $0.08 \mathrm{mg}$ dextran $\mathrm{T}-70)$. The progesterone antiserum was raised against a progesterone-1 1 -bovine serum albumin conjugate and cross-reacted $4 \cdot 2 \%, 0 \cdot 6 \%$ and $1 \cdot 0 \%$ with $20 \alpha$-dihydroprogesterone, $20 \beta$-dihydroprogesterone and $17 \beta$-hydroxyprogesterone respectively. Cross-reaction against all other steroids tested was $<0.1 \%$. Sensitivity of the assay was $0.35 \mathrm{ng} / \mathrm{ml}$ and the intra- and inter-assay coefficients of variation were $12 \cdot 6 \%$ and $15 \cdot 6 \%$ respectively.

Pregnancy was determined by a failure of ewes to return to oestrus and fetal numbers were estimated using real-time ultrasonic scanning 60 days after mating. Data were analysed using $\chi^{2}$ tests and analysis of variance (SYSTAT).

\section{Results}

When ewes were fed high rations the pregnancy rate was significantly reduced compared to that of ewes fed medium or low rations unless they were given a progesterone supplement (CIDR) over Days 8-14 after mating (Table 1). Progesterone supplementation had no influence on pregnancy rate when ewes were fed low or medium rations. Differences in percentage of fetuses per ewe pregnant (Table 1) were not significant $(P>0.05)$. Mean liveweight changes during the 12-day nutrition treatment period represented a gain of $0.4 \%$ and decreases of $2 \cdot 6 \%$ and $9 \cdot 8 \%$ of initial liveweights in the high, medium and low ration groups.

Table 1. The influence of level of nutrition and progesterone supplement (CIDR Days 8-14 after mating) on the percentage of ewes pregnant and the percentage of fetuses per ewe pregnant

\begin{tabular}{lcccc}
\hline & \multicolumn{2}{c}{ Ewes pregnant (\%) } & \multicolumn{2}{c}{ Fetuses/ewe (\%) } \\
\cline { 2 - 5 } $\begin{array}{l}\text { Level of } \\
\text { nutrition }\end{array}$ & Control & CIDR & Control & CIDR \\
\hline High & $48^{\mathrm{ax}}$ & $76^{\mathrm{by}}$ & 132 & 132 \\
Medium & $68^{\mathrm{b}}$ & $65^{\mathrm{b}}$ & 135 & 150 \\
Low & $67^{\mathrm{b}}$ & $60^{\mathrm{b}}$ & 129 & 148 \\
\hline
\end{tabular}

Different superscripts denote significant differences: $a, b$ : $P<0.05 ; \mathrm{x}, \mathrm{y}: P<0.01$.

Table 2. Peripheral plasma progesterone concentrations on Day 12 after mating from ewes fed high, medium or low levels of nutrition on Days 2-14 after mating and treated with exogenous progesterone (CIDR) on Days 8-14 after mating

\begin{tabular}{lccc}
\hline & \multicolumn{3}{c}{ Level of nutrition } \\
\cline { 2 - 4 } & Low & Medium & High \\
\hline $\begin{array}{l}\text { Control ewes } \\
\text { CIDR-treated }\end{array}$ & $3 \cdot 2 \pm 0 \cdot 20(55)$ & $2 \cdot 0 \pm 0 \cdot 20(55)$ & $1 \cdot 5 \pm 0 \cdot 16(54)$ \\
ewes & $5 \cdot 4 \pm 0 \cdot 34(51)$ & $4 \cdot 2 \pm 0 \cdot 32(55)$ & $2 \cdot 8 \pm 0 \cdot 20(55)$ \\
\hline $\begin{array}{l}\text { Values are mean } \pm \text { s.e.m. for the no. of ewes in parentheses (5 samples } \\
\text { lost during centrifugation). }\end{array}$
\end{tabular}




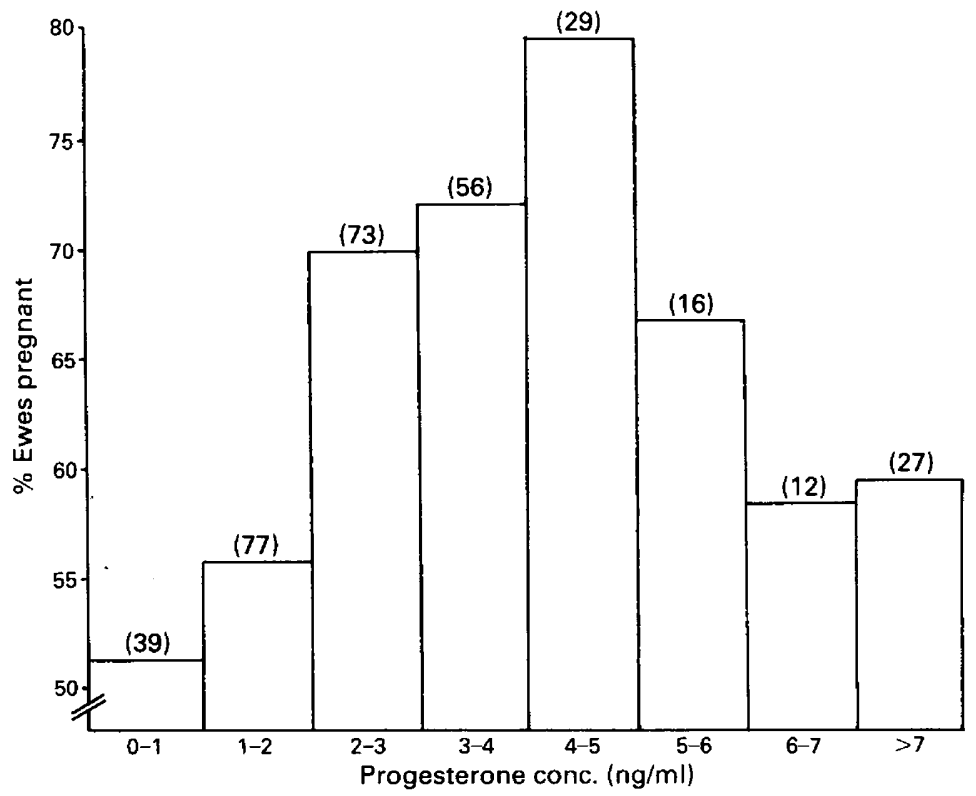

Fig. 1. Relationships between peripheral progesterone concentration measured 12 days after mating and pregnancy rate in sheep. Data are pooled for nutrition and progesterone treatment groups. Figures in parentheses are for the number of ewes in each class.

Peripheral progesterone concentrations measured 12 days after mating (Table 2) showed an inverse relationship with increasing nutrition. Ewes fed high rations in the control group had mean peripheral progesterone concentrations which were less than $50 \%$ of those of ewes fed low rations. Insertion of a CIDR device corrected this deficiency. Nutrition levels and exogenous progesterone significantly $(P<0.001)$ affected Day 12 plasma progesterone concentrations. There was no interaction between these two factors. When the total distribution of pregnant ewes was plotted against plasma progesterone concentration (Fig. 1), it was evident that at least $2 \mathrm{ng}$ progesterone $/ \mathrm{ml}$ plasma was necessary for satisfactory conception. Reductions in conception rates also occurred when plasma progesterone concentrations were higher than $4-5 \mathrm{ng} / \mathrm{ml}$.

\section{Discussion}

These results demonstrate that ewes fed high rations after mating had reduced plasma progesterone concentrations and showed an increase in embryonic mortality. Over-feeding has previously been linked with embryonic mortality (El-Sheikh et al., 1955; Foote et al., 1959; Cumming et al., 1975; Brien et al., 1977, 1981), but the mechanism(s) causing this loss has not been understood. In studies using exogenous progestagen therapy (Pearce et al., 1984; Peterson et al., 1984; Smith et al., 1985) no mention was made of nutritional conditions in early pregnancy. We believe there is now an explanation for the conflicting reports in the literature. An increase in pregnancy rate with exogenous progesterone treatment will only occur when ewes are fed high rations or are in a rising nutritional state after mating.

The inverse relationship between nutrition and peripheral progesterone concentration has previously been reported by Parr et al. (1982) and Williams \& Cumming (1982). In the former study this phenomenon occurred when ovariectomized ewes were given controlled daily doses of 
progesterone. This effect of nutrition on plasma progesterone concentrations may be due to a higher clearance rate of progesterone since blood flow to the liver of ewes increases with feeding (Bensadoun \& Reid, 1962) and the liver is a major site of progesterone catabolism (Bedford et al., 1974). If compensatory changes in secretion rate from the ovary do not occur then the peripheral progesterone concentration would be altered, and some ewes, when overfed, would have peripheral progesterone concentrations below the threshhold necessary for embryo survival.

The reduction in pregnancy rates of ewes with peripheral progesterone concentrations above $5 \mathrm{ng} / \mathrm{ml}$ on Day 12 was probably due to direct effects of undernutrition (Edey, 1969) rather than elevated progesterone. Ewes fed maintenance rations and given high exogenous doses of progesterone do not suffer high embryonic losses (Parr et al., 1982).

In conclusion, we have demonstrated an association in sheep between nutrition, endocrinology and reproduction which could have important implications for other animal species. Knowledge of this interaction will be important in the future when making decisions about feeding levels for ewes in early pregnancy.

This work was supported by the Australian Wool Research Trust Fund. The CIDRs were kindly supplied by Hoechst Australia Ltd. We thank Mr P. Langdon, Mr T. Squires, Mr C. Toohey, Mr E. Pilatti, Mr T. Grazebrook and Mr G. Holland for technical assistance; and Dr L. P. Cahill, Dr L. D. Staples and Dr I. J. Clarke for comments on the manuscript.

\section{References}

Bedford, C.A., Harrison, F.A. \& Heap, R.B. (1974) The splanchnic, uterine, ovarian and adrenal uptake of progesterone and $20 \alpha$-dihydroprogesterone in the pregnant and non-pregnant sheep. J. Endocr. 62, $277-290$.

Bensadoun, A. \& Reid, J.T. (1962) Estimation of rate of portal blood flow in ruminants; effect of feeding, fasting and anaesthesia. J. Dairy $S c i .45,540-543$.

Brien, F.D., Cumming, I.A. \& Baxter, R.W. (1977) Effect of feeding a lupin grain supplement on reproductive performance of maiden and mature ewes. J. agric. Sci., Camb. 89, 437-443.

Brien, F.D., Cumming, I.A., Clarke, I.J. \& Cocks, C.S. (1981) Role of plasma progesterone concentrations in early pregnancy of the ewe. Aust.J. exp. Agric. Anim. Husb. 21, 562-569.

Cumming, I.A., Blockey, M.A. de B., Winfield, C.G., Parr, R.A. \& Williams, A.H. (1975) A study of relationships of breed, time of mating, level of nutrition, liveweight, body condition and face cover to embryo survival in ewes. J. agric. Sci., Camb. 84, $559-565$.

Davis, I.F., Kerton, D.J., Parr, R.A., White, M.B. \& Williams, A.H. (1986) Hormone supplementation to increase fertility after uterine artificial insemination in ewes. Proc. Aust. Soc. Anim. Prod. 16, 171-173.

Denamur, R. \& Martinet, J. (1955) Effets de l'ovariectomie chez la brebis pendant la gestation. C. r. Séanc. Soc. Biol. 149, 2105-2107.

Edey, T.N. (1969) Prenatal mortality in sheep: a review. Anim. Breed. Abstr. 37, 173-190.

El-Sheikh, A.S., Hulet, C.V., Pope, A.L. \& Casida, L.E. (1955) The effect of level of feeding on the reproductive capacity of the ewe. J. Anim. Sci. 14, 919-929.
Fairclough, R.J., Hunter, J.T. \& Welch, R.A.S. (1975) Peripheral plasma progesterone and utero-ovarian prostaglandin $F$ concentrations in the cow around parturition. Prostaglandins 9, 901-914.

Foote, W.C., Pope, A.L., Chapman, A.B. \& Casida, L.E. (1959) Reproduction in the yearling ewe as affected by breed and sequence of feeding levels. I. Effects on ovulation rate and embryo survival J. Anim. Sci. 18, $453-462$.

Kerton, D.J., McPhee, S.R. \& Davis, I.F. (1986) Cronolone (FGA) treatment after A.I. in ewes does not affect embryo survival. Proc. Aust. Soc. Anim. Prod. 16, 417, Abstr.

Parr, R.A., Cumming, I.A. \& Clarke, I.J. (1982) Effects of maternal nutrition and plasma progesterone concentrations on survival and growth of the sheep embryo in early gestation. J. agric. Sci., Camb. 98, $39-46$.

Pearce, D.T., Gray, S.J., Oldham, C.M. \& Wilson, H.R. (1984) The use of intravaginal sponges and PMSG. Proc. Aust. Soc. Anim. Prod. 15, 164-170.

Peterson, A.J., Barnes, D., Shanley, R. \& Welch, R.A.S. (1984) Administering progesterone after mating improves pregnancy rate in sheep. Proc. Endocr. Soc. Aust. Suppl. 27, 13, Abstr.

Smith, J.F., Farquhar, P.A. \& Welch, R.A.S. (1985) Failure of progesterone administered mid-cycle to influence conception rate or embryonic mortality. Proc. Endocr. Soc. Aust. Suppl. 28, 9, Abstr.

Williams, A.H. \& Cumming, I.A. (1982) Inverse relationship between concentration of progesterone and nutrition in ewes. J. agric. Sci., Camb. 98, 517-522.

Received 24 October 1986 